\title{
SOCIAL INNOVATION LIVING LAB AS A METHODOLOGY FOR CONCEPTUAL DESIGN RESEARCH
}

\author{
Grzegorz Baran* $\odot$ http://orcid.org/0000-0003-2480-8058
}

\begin{abstract}
Background. Given the specificity and importance of social innovation as the processes of converting novel ideas and solutions of crucial social problems into value for society, they cannot be research and designed if taken out from real-life environment. A living lab approach has become a promising methodology for social innovation research and design, wich offer means of developing and testing innovations in co-creation with users and other stakeholders in real-life settings.
\end{abstract}

Research aims. Given that a living lab is above all a research and design methodology, this research study is aimed at developing the inquiry processes on which the functioning of a social innovation living laboratory is based and which are the basis of conceptual design research framework.

Methodology. This research study was realized with conceptual research, wherein the existing knowledge was used as a source of reasoning leading to solve the scientific problem. The observing and analyzing existing information on cognitive processes occurring within living laboratories and their interpretation in the light of knowledge about the processes of creating social innovations led to solve the scientific problem.

Key findings. The original conceptual design research framework for a social innovation living lab understood as a research and design methodology. Proposed research framework enables to combine existing knowledge with the experiences from its application for theory testing and further development.

Keywords: living lab, social innovation, design, design-led approach, conceptual design research

JEL Codes: O3, M1, L2

\footnotetext{
*Jagiellonian University in Kraków. E-mail: g.baran@uj.edu.pl
} 


\section{INTRODUCTION}

This research study is aimed at developing the processes of inquiry on which the functioning of a social innovation living laboratory is based and which are the basis of conceptual design research framework. It presents the conceptual phase of the undertaken considerations, which leads to the outline of such a process within a broader conceptual framework based on the living lab concept. The choice of the research problem resulted from the research gap identified in the literature study. The literature review has proved the significant lack of research studies on processes of creating and developing social innovation, including the lack of research on the potential use of research laboratories in which such innovations could be designed.

Social innovation has recently enjoyed growing interest in both the world of science and policymakers (Pol \& Ville, 2009; Borzaga \& Bodini, 2014). This concept is considered is even considered as an alternative for traditional governing (Bekkers et al., 2013). Social innovations as new ideas that address unmet social needs more effectively than current solutions (Mulgan, 2006; Bason, 2010; Caulier-Grice et al., 2012; European Commission, 2019), are social in their ends and in their means (Murray et al., 2010).

Given the evident shortage of systematic theoretical and empirical research in the field of social innovation (also in the area of solid methodological background of such research), the development of methods and tools for researching and designing social innovations is necessary. At the same time, as both a component and a cause of social change, social innovation cannot be researched and created in closed labs, but in real-life settings. Thus, this paper presents a methodological proposal for social innovation living lab, which takes into account social changes that such innovations cause in real social situations.

This paper lays out a conceptual framework that can improve understanding of the role of the particular mode of reasoning that is afforded by living labs. Consequently, the aim of the research was the discovery of the implicit process of reasoning that is typical in design sciences and its reconstruction for the needs of scientific discovery in social innovation development with the use of living labs. The paper presents a proposal for an operating method of such a laboratory that systematizes reasoning processes leading to social innovation. The subject of research attention is not the way of organizing such 
a laboratory or the place of research, but the living las as a research approach to social innovation. The laboratory itself, due to the specificity of social innovations, cannot be separated from the everyday life situations in which the innovations occur.

\section{METHOD}

While reviewing the worldwide literature, there was identified the significant lack of research on using the methodology of living lab for creating social innovations. Consequently, the research effort was aimed at developing a conceptual framework of such a methodology framed from the perspective of design-led approach to innovations.

The research was carried out with use of conceptual research framework based on the observing and analyzing existing information on cognitive processes occurring within living laboratories and their interpretation in the light of knowledge about the processes of creating social innovations. This means that the existing knowledge was used as a source of reasoning leading to solve the scientific problem.

The analysis of the knowledge available in the scientific literature on living laboratories and their potential in the development of social innovations in the context of design-led approach to innovation resulted in designing a cognitive model within social innovation living labs. This is also a conceptual framework of a methodology for conceptual design research which can be helpful in the future in combining existing knowledge with the experiences from its application for theory testing and further development.

\section{BACKGROUND}

The subject and fundamental context of the undertaken research are twofold: social innovations as the processes of converting novel ideas and solutions of social problems into value for society and living labs interpreted as a methodology that can facilitate such innovation research and design.

\section{A CONCEPT OF SOCIAL INNOVATION}

Social innovation is a phenomenon and a concept that have recently enjoyed growing interest in both the world of science and policymakers. 
This term has come into common parlance in recent years (Pol \& Ville, 2009). As C. Borzaga and R. Bodini note, "over the past few years there has been a growing interest on the part of the scientific community (and, more recently, of policymakers) in the concept of social innovation" (Borzaga \& Bodini, 2014, p. 411). What's more, there have been ideas for some time that social innovations can fill certain deficits of traditional governing. As Bekkers et al. write that:

... at this moment the innovation journey on which the public sector in many countries have embarked, sails under the flag of "social innovation". The British prime-minister Cameron incorporated social innovation in his view on the so-called "Big Society", in which he embraces the idea of social entrepreneurship and social innovation as an alternative for traditional governing (Bekkers et al., 2013).

Social innovation is depicted as a relevant topic also by the European Commission. On their website, social innovations are defined as:

... new ideas that meet social needs, create social relationships and form new collaborations. These innovations can be products, services or models addressing unmet needs more effectively. The European Commission's objective is to encourage market uptake of innovative solutions and stimulate employment (European Commission, 2019).

According to Bekkers et al., innovation inspires people and policy makers as a mechanism of radical change (Bekkers et al., 2013). Being social in their ends and in their means (Murray et al., 2010, p. 3), social innovation is an important concept for both society and social sciences development as they promise the radical change of the world we live in for the better (Mumford, 2002; Pol \& Ville, 2009; Howaldt \& Schwarz, 2010; Neumeier, 2012; Olejniczuk-Merta, 2013). They offer a new potential of our lives improvement by better use of novel methods, technologies and tools, introducing new patterns of practices, interactions and social relations, and even new structures, organizational forms and social institutions (Baran, 2018).

According to Caulier-Grice et al.,

social innovation has also emerged as a response to growing social, environmental and demographic challenges - often called "wicked" problems because they are complex, multi-faceted, involve a range of stakeholders and are, by their nature, impossible to solve (Caulier-Grice et al., 2012, p. 5). 
The majority of research and policies have been focused on technological innovation. However, we need social innovation to effectively use that knowledge for human empowerment and development (Caulier-Grice et al., 2012). As Christian Bason notes, social innovation embraces "the process of creating new ideas and converting them into value for society" (Bason, 2010, p. 8; Zurbriggen \& Lago, 2019, p. 439).

Social innovation is still a vague concept and interpreted in numerous manners (Mulgan, 2006; Olejniczuk-Merta, 2013; Cajaiba-Santana, 2014). Despite the growing scientific interest in social innovations (Mulgan, 2006; Cajaiba-Santana, 2014), this term still seems to be treated as a buzz word (Pol \& Ville, 2009). There is still not even a relatively common agreement of what this type of innovation exactly is (Pol \& Ville, 2009; Caulier-Grice et al., 2012). As Pol \& Ville write, "the term 'social innovation' has entered the discourse of social scientists with particular speed, but there is no consensus regarding its relevance or specific meaning in the social sciences and humanities" (Pol \& Ville, 2006, p. 878).

While reviewing the scientific literature it was found the evident shortage of systematic theoretical and empirical research in the field of social innovation (also in the area of solid methodological background of such research). Despite many cases of successful social innovations in numerous fields (from health care, hospices and online self-help health groups, through microcredits, consumer cooperatives, fair trade movement, to zero-carbon housing development and community wind farms), the processes of social innovation remain understudied and are described at the level of anecdotes and vague generalizations (Mulgan, 2006, p. 146).

Borzaga and Bodini trace the idea of social innovation as far back as Max Weber and Emile Durkheim (Borzaga \& Bodini, 2014). They and other sociologists of that time have promoted innovation in the social field as a part of larger processes of social change (Ionescu, 2015, p. 55). According to Borzaga and Bodini, the first centers focused on this topic date back to the late 1980s and early 1990s. However, the popularity of the concept has dramatically risen in the first decade of the $21^{\text {st }}$ century as evidenced by numerous specialised research institutions, such as the Center for Social Innovation at Stanford Graduate School of Business in the United States, the Social Innovation Exchange by the Young Foundation in London or the Netherlands Centre for Social Innovation (Borzaga \& Bodini, 2014, pp. 411-412). 
Recently, scientists have offered a number of definitions of social innovation, which underline various aspects of the term and present varying degrees of specificity (Mumford, 2002; Mulgan, 2006; Bergman et al., 2010; Olejniczuk-Merta, 2013; Manzini, 2014; Kwaśnicki, 2015). Although this concept is omnipresent in public debates, there are significant differences in the way social innovation is understood, conceptually, but also as a social practice and action (Ionescu, 2015, p. 57).

On the one hand, social innovations are still innovations. Consequently, there are not social innovations without an aspect of novelty. One of the most concise definition of innovation was formulated by Steward et al. as "successful exploitation of new ideas" (Steward et al., 2009, p. 7). The aspect of novelty distinguishes social innovation from other changes and is noted by the majority of authors dealing with social innovation (Mumford, 2002; Mulgan, 2006; Olejniczuk-Merta, 2013; Manzini, 2014; Cajaiba-Santana, 2014).

On the other hand, transferring its common meaning linked to particular scientific and technological instances causes some difficulties in conceptualizing the term (Ionescu, 2015, p. 58). The difficulties considered here are mainly due to the fact that the novelty aspect of classic innovation concerns primarily the result and not the process of creating innovation. Social innovation (as said before) are social both in their ends and in their means. As Murray et al. say, social innovations encompass those ideas that simultaneously meet social needs and create new social processes and relationships. Social innovations are "innovations that are both good for society and enhance society's capacity to act" (Murray et al., 2010, p. 3).

There are then some reasons to anchor the concept of social innovation in the theory of social change. While some definitions focus primarily on meeting social needs, they overlook this element of social change. According to OECD,

... the key distinction is that social innovation deals with improving the welfare of individuals and communities through employment, consumption and/or participation, its expressed purpose being to provide solutions for individual and community problems" (OECD, 2011, p. 21).

Olejniczuk-Merta argues that the effects of all social innovations contribute to improving the quality of life, regardless of the scale of 
occurrence of these effects and whether they appear directly or indirectly, intentionally or unintentionally (Olejniczuk-Merta, 2013, p. 29).

Most researchers and authors of publications admit that social innovations are the result of social motivation that is caused by a desire to meet social needs (Mumford, 2002; Mulgan, 2006; Pol \& Ville, 2009; Caulier-Grice et al., 2012; Olejniczuk-Merta, 2013; Manzini, 2014; Kwaśnicki, 2015). However, to be able to call a given solution a social innovation, this element of social change is necessary (in terms of processes, relationships, or even understanding and interpretation of a social problem). Consequently, we can consider narrowing the concept of social innovation only to those changes or solutions that are social (excluding technological solutions). However, not the nature of a solution determines the nature of innovation but how this innovation influences social practice patterns, relationships and interactions (Mumford, 2002; Pol \& Ville, 2009; Howaldt \& Schwarz, 2010; Olejniczuk-Merta, 2013; Cajaiba-Santana, 2014; Manzini, 2014; Kwaśnicki, 2015).

However, no equal sign can be put between social innovation and social change. According to Howaldt and Schwarz, "the material difference between social change and social innovation rests in the latter being associated with planned and coordinated actions" (Howaldt \& Schwarz, 2010, p. 28). They claim that social innovations are components of social change and at the same time they are the most important cause of social change. However, they (although intentional and goal-oriented) social innovation can initiate new social practices also in a partly unintentional way (Howaldt \& Schwarz, 2010, p. 28).

The above findings are a premise to conclude that social innovations are clearly different from other types of innovations. What is more, we still know very little about the processes of their creation and development (Mulgan, 2006; Pol \& Ville, 2009; Howaldt \& Schwarz, 2010; Caulier-Grice et al., 2012; Neumeier, 2012). Social innovation is driven by intentional and planned actions but they can initiate a bigger and also unintentional social change (Mulgan, 2006; Howaldt \& Schwarz, 2010). Consequently, social innovation as both a component and an important cause of social change cannot be created completely in closed laboratories. The research of social innovation should be carried out where such innovations arise and where they affect people's real lives.

Given the specificity and importance of social innovations presented above, we need methods and tools for researching and designing social 
innovations that take into account social changes that they cause in real social situations. One of such proposals is the living labs methodology, increasingly used in a public sector (Dekker et al., 2019), which can be adapted for the needs of researching and designing social innovations. Therefore, the next section presents the living lab concept.

\section{LIVING LABS}

According to Coorevits et al., along with the digital revolution nowadays there is observed an increased tendency to extend the research processes beyond the limitations of the closed laboratories towards the highly dynamic environment of "real life". Products can be tested much better in natural than laboratory settings because people tailor their behaviour to the setting they are in (Coorevits et al., 2018, p. 40). Consequently, the growing value of living labs is observed. They are regarded as long term environments for open innovation that enable experimentation with real users in real contexts (Hillgren, 2013; Veeckman et al., 2013; Leminen et al., 2012; Følstad, 2008).

While reviewing the scientific literature on living labs, this concept was found still in the initial stage of development (Eriksson et al., 2005; Følstad, 2008; Klimowicz, 2015; Keyson et al., 2017; Dekker et al., 2019). The concept of living labs originates from Professor William Mitchell at MIT. It was initially used to observe the living patterns of users in smart homes, where real people was observed in their usage of emerging technologies in the setting of a real home (Eriksson et al., 2005). According to Bergvall-Kåreborn et al., "today, there is an ongoing trend in Europe to tailor a living lab concept in wider use to enhance innovation, inclusion, usefulness and usability of ICT and its applications in the society" (Bergvall-Kåreborn et al., 2009). Living labs are also seen as a promising methodology for public administration research to design and study public innovations (Bekker et al., 2019).

Living labs are defined in numerous ways with an emphasis on various aspects (mainly an emerging approach to innovation or an infrastructure that enable user-driven innovation practices). According to Veeckman et al., living lab is an emerging open innovation approach that involves multiple stakeholders (including users) to co-create value that eventually leads to innovation. It delivers a new way of structuring research through validation and testing in real-life contexts (Veeckman et al., 2013, p. 6). Similarly, Schuurman et al., who write about living lab as 
a structured approach to open innovation. They describe a living lab approach as a five phases methodology: i) contextualization, ii) selection, iii) concretization, iv) implementation, and v) feedback. It resembles a quasi-experimental design, with a pre-test, a real-life intervention, and a post-test. However, the methodological basis of these five phases remains still unexplored (Schuurman et al., 2016, p. 8).

Leminen et al. put emphasis on living labs as networks that support creating innovations that better meet user needs. As physical regions or virtual realities in which stakeholders create public-private-people partnerships of firms, public agencies, universities, institutes, and users, living labs help to collaborate for creation, prototyping, validating, and testing of new technologies, services, products, and systems in real-life contexts. They offer a research "think-tank" and platform to help companies to apply user-driven innovation practices (Leminen et al., 2012). According to Romero Herrera, a living labs offer a socio-technical infrastructure to support user-centric innovation processes. They deliver collaborative platforms where professionals from different disciplines work together with future users and public and private stakeholders to generate solutions that are rooted in the settings of daily life practices. The users play an active role in generating and applying contextualized practice-based knowledge in innovation processes (Romero Herrera, 2017).

Based on a systematic literature review, Dekker et al. present a living lab as an approach established on four common elements: (1) being a research and development process of innovation, (2) being a collaboration between multiple stakeholders, (3) taking place in a real-life setting, (4) involving users as co- creators (Dekker et al., 2019). Building upon explored research studies, they define "living labs are a research and design methodology applied by research institutes in cooperation with public and private partners for developing and testing innovations in co-creation with users in real-life settings" (Dekker et al., 2019, p. 5).

Given the specificity of social innovations as usually open and ill-structured problems, living labs seem to be a methodology that can offer an alternative to linear and closed modes of problem solving. While an increasing number of managers are interested in living labs as a way to transform their conventional $R \& D$ into open-innovation model (Leminen et al., 2012, p. 6), the living lab and open innovation concepts seem to be the promising alternative for intentional and goal-oriented 
development of social innovation. As long as social innovations may trigger unintentional social changes, they have to be researched, designed and accomplished in the real-life settings. Thus, living labs that can facilitate user-centric and user-driven innovation practices in open and distributed innovation processes in real-life contexts (Bergvall-Kåreborn et al., 2009), they could offer significant support in researching and designing social innovation.

\section{RESULTS}

The research undertaken is ultimately aimed at developing the process of inquiry on which the functioning of a social innovation living laboratory is based. This presents the initial phase of the undertaken considerations, which leads to the outline of such a process within a broader conceptual framework, which is depicted in this section.

Social innovation living lab can be interpreted as a kind of ecosystem for inquiry processes that lead to create and experiment with novel ideas and convert them into solutions of serious social problems (Fig. 1). Such an ecosystem is more than a research process, but at the same time it is not a traditionally understood innovation ecosystem. While innovation ecosystems are usually defined as hubs or platforms that can connect enterprises, leading technology companies, startup environments, universities, investors financing research and development, central and local administration to support the development of innovative companies in a country, region or within an organization (Gawer \& Cusumo, 2014), they can also be described as the set of activities along the innovation processes and their drivers within and around the offered system solutions (Rohrbeck et al., 2009).

As an analogy to the biological ecosystem (which includes all living organisms in an area and its physical environments functioning together as one unit), innovation ecosystem models the economic relationships that are formed between actors or entities whose goal is to enable technology development and innovation (Jackson, 2011). According to Jackson, an innovation ecosystem consists of two distinct economies: the research economy, which is driven by fundamental research, and the commercial economy, which is driven by the marketplace expectations (Jackson, 2011). For the research economy, more important than the actors involved in the innovation ecosystem are the relationships and processes that lead to the creation of innovations. 


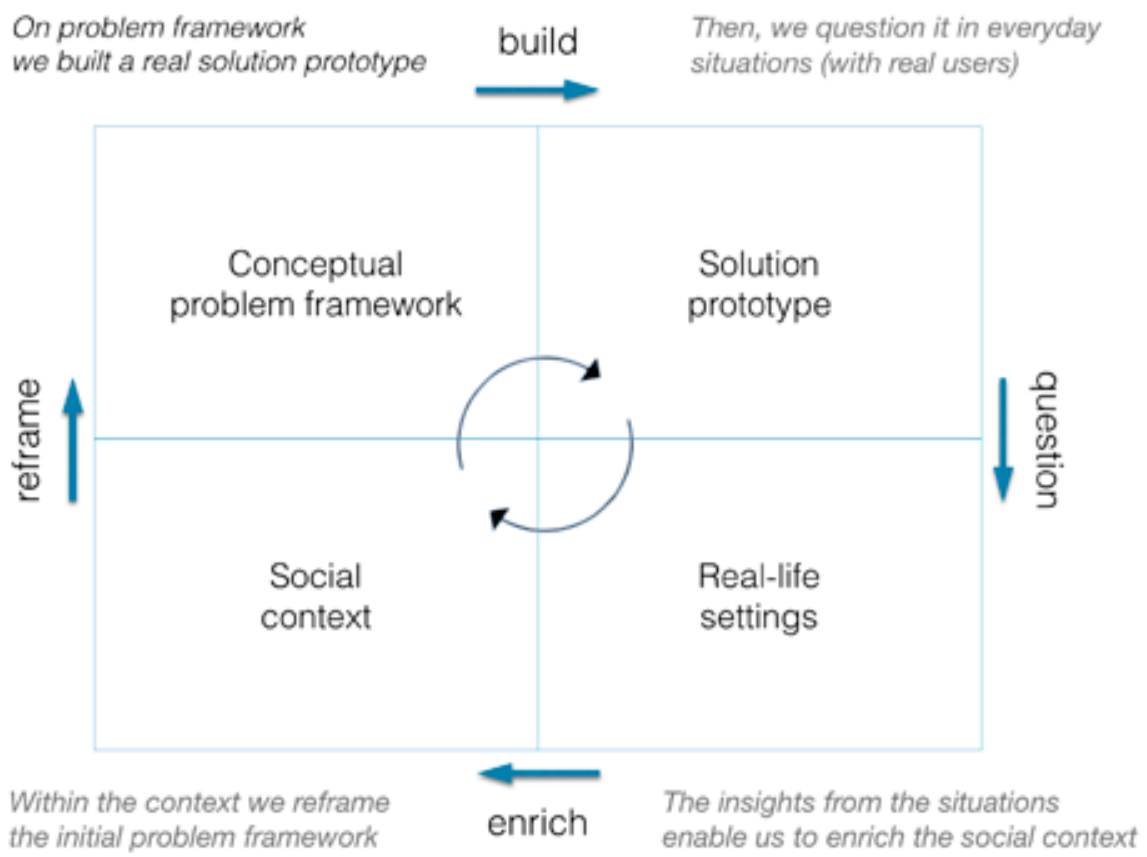

Figure 1. A conceptual design research framework for social innovation living lab

Source: Own elaboration.

Assuming that an ecosystem is a living environment (as a community of living organisms within the nonliving components of their environment), a design research ecosystem is the environment that afford inquiry processes that can root designed solutions in real-life settings. Thus, design research requires building the entire ecosystem fostering eligible processes of inquiry.

The living lab methodology combined with the design-led approach above all offer the possibility of rapid prototyping of innovative ideas and experiment with novel solutions in real life situations. First, we test the prototype of a solution and thus its assumptions adopted as part of the conceptual problem solution, observing how this prototype behaves in specific everyday situations. Creating and testing prototypes is used to experiment with various solutions simultaneously. A prototype is used not to refine the final solution, but to get the feedback and test conclusions drawn from earlier stages of the research (Kelley \& Kelley, 
2015; Brown, 2016). According to Kelley and Littman, prototyping is both one of the stages of the innovation design process and a philosophy that affords to move forward even when there are still many unknowns (Kelley \& Littman, 2001, p. 5). Secondly, a living lab delivers an opportunity to involve users in co-creating the emerging solution (Baran, 2013; Ehn, 2008; Voorberg et al., 2015).

As Coorevits et al. prove, a living lab uses a multi-method approach, engages users and multiple stakeholders, and operates in a real-life setting so that the different parties involved can co-create a solution (Coorevits et al., 2018, p. 41). They write about the importance of real-life testing in early stages of the innovation process and consequently they introduce the notion of a field test in living labs. This is "a user study in which the interactions of test users with an innovation in the context of use are tested and evaluated" (Coorevits et al., 2018, p. 42).

A study from Schuurman et al. suggests that a living lab yields maximal value when evolving from a concept towards a prototype. Besides living lab is a perfect "playground" to test and validate assumptions from the open innovation literature (Schuurman et al., 2016, p. 7). As said before, living lab as a methodology affords a new way of arranging research through validation and testing in real-life settings (Veeckman et al., 2013), which resembles a quasi-experimental design, with a pre-test, a real-life intervention, and a post-test (Schuurman et al., 2016).

However, the inquiry process begins much earlier. It is rooted in a conceptual problem framework which is framed within the broad social context (of both a problem and a researcher). This context contains also the all existing knowledge a solution is being built on (Fig. 1). The starting point of the research process that leads to social innovation is a conceptual problem framework. It is a kind of analytical tool and structure within which we can build design research perspective towards a problem. It gives an overall picture of a problem and can be applied to the whole category of akin problems in several contexts.

Dzbor and Zdrahal introduce problem framing as an interpretation of a problem with using selected conceptual primitives (Dzbor \& Zdrahal, 2002). As they note, "the need for a problem interpretation reflects the fact that the designers are rarely given a detailed specification of a problem" (Dzbor \& Zdrahal, 2002). According to Dorst and Cross, framing a design problem is a key aspect of creativity. The more time we spend in understanding and defining a problem, and consequently looking for an eligible frame of reference in forming conceptual 
structures, the better a solution we can achieve (Dorst \& Cross, 2001). Dzbor and Zdrahal write about an idea of 'co-evolving' design solutions and specifications. According to them,

... the initial incomplete requirements are transformed onto an acceptable specification of a design problem and its solution. Partial solutions influence the requirements, and in turn, the modified requirements refine the solutions, thus revealing the aforementioned co-evolution. Empirically, such a co-evolution is associated with the shaping (framing) of a design situation (Dzbor \& Zdrahal, 2002).

The problem solving process for social innovations does not start with the precise formulation of the problem. Eric von Hippel and Georg von Krogh note that in informal problem solving we often solve a problem without its previous formulation. They write about a need-solution pair to emphasize that a need and a solution are often discovered together (Hippel \& Krogh, 2016). According to them, "what we see is a problem-solving process that begins with identification of viable need-solution pairs rather than with the formulation of a problem" (Hippel \& Krogh, 2016, p. 208).

Dorst and Cross noticed a similar patter within design research. They suggest that design process is not so much a creative leap from a problem to a solution as the building of a bridge between the problem space and the solution space. This leads to identification of a key concept by the co-evolution of problem and solution spaces (Dorst \& Cross, 2001, p. 435). What we have at the beginning of the process is though only a more or less relevant problem framework. In a period of exploration problem and solution spaces are evolving until we are able to identify a problem-solution pair as a bridge between problem and solution spaces (Dorst \& Cross, 2001, p. 435).

\section{DISCUSSION AND CONCLUSIONS}

While studying the scientific literature, it is found that design is gaining popularity as an innovation approach to address complex social problems (Bason, 2010; van der Bijl-Brouwer et al., 2015; Baran, 2018; Dekker et al., 2019). At the same time, the literature review has revealed the significant lack of research studies on social innovation and especially the processes of its generating. 
Given the specificity of social innovations, we need novel methods and tools for researching and designing such interventions that take into account social changes that they cause in real life situations. One of such proposals is the living lab methodology, which can be adapted for the needs of researching and designing social innovations (Leminen et al., 2012; Dekker et al., 2019). Along with the digital revolution there is observed an increased tendency to extend the research processes beyond the limitations of the closed laboratories towards the real-life settings (Coorevits et al., 2018). Consequently, we observe the growing value of living labs as long term environments for open innovation that enable experimentation with real users in real contexts (Hillgren, 2013; Veeckman et al., 2013; Leminen et al., 2012; Følstad, 2008).

The study of scientific literature has proven that this concept is still in the initial stage of development (Eriksson et al., 2005; Følstad, 2008; Klimowicz, 2015; Keyson et al., 2017; Dekker et al., 2019). While living labs offer a novel way of structuring research through validation and testing in real-life contexts (Veeckman et al., 2013), their methodological basis is still not thoroughly explored (Schuurman et al., 2016; Dekker et al., 2019). Thus, the research study was aimed at creating a novel approach to designing and accomplishing social innovation in more intentional and goal-oriented way. Consequently, the conceptual design research framework as a methodological proposal for a social innovation living lab has been developed as the result of this research study.

The conceptual design research framework for a social innovation living lab proposed in this paper is to some degree in line with other methodological proposals for living labs we can find in a scientific literature (Dorst \& Cross, 2001; Schuurman et al., 2016; Dekker et al., 2019). Both the conceptual design research framework and the proposal from Schuurman et al. (2016) of the five phases methodology (introduced in the result section) assume embedding the research process in a broader social and theoretical context, and validation and testing solution prototypes/concretizations in real-life settings. These five phases: i) contextualization, ii) selection, iii) concretization, iv) implementation, and v) feedback enable to get reliable feedback by: (1) exploring new knowledge for innovation development, (2) experimenting with the innovation prototypes, and (3) evaluating the innovation (Schuurman et al., 2016, p. 10). 
The proposed conceptual design research framework is also consistent with the assumptions on a living lab approach made by Dekker, who claims that this approach should be established on four common elements: (1) being a research and development process of innovation, (2) being a collaboration between multiple stakeholders, (3) taking place in a real-life setting, (4) involving users as co-creators (Dekker et al., 2019). This proposal is also based on the assumption that a living lab is more a new manner of structuring research through validation and testing in real-life settings than an infrastructure (Veeckman et al., 2013). In many cases, a living lab does not even need a testbed, but a product or service that remains available to its users for a certain period of time is enough to do such a research (Dekker et al., 2019).

The proposed research framework for a living lab also delivers the proposal for conceptual research. Such research involves the development or adoption of a new conceptual frame as an assumption that applying a certain working principle is able to create a specific value (Dorst, 2010). Thus, the inquiry leads not only to design innovative solution to a specific problem, but also to conceptual development. In the conceptual design research two processes are intertwined: (1) creating a new solution which is based on a certain working principle and (2) testing a certain working principle or developing a novel working principle. The first of them has mainly a practical purpose, the second leads to the creation of new knowledge. Thus, by creating a practical solution to a specific social problem we enrich the knowledge about the social context of the problem.

\section{REFERENCES}

Baran, G. (2013). Marketing wspóttworzenia wartości z klientem: spotecznotwórcza rola marketingu $w$ procesie strukturacji interakcyjnego środowiska doświadczeń. Kraków: Instytut Spraw Publicznych Uniwersytetu Jagiellońskiego.

Baran, G. (2018). Design-led approach to social innovation. Przedsiębiorczość i Zarzqdzanie, 19(9), vol. 3, 467-482.

Bason, C. (2010). Leading Public Sector Innovation: Co-creating for a Better Society. Bristol: Policy Press.

Bekkers, V. J. J. M., Tummers, L. G. \& Voorberg, W. H. (2013). From Public Innovation to Social Innovation in the Public Sector: A Literature Review of Relevant Drivers and Barriers. Rotterdam: Erasmus University Rotterdam. 
Bergman, N., Markusson, N., Connor, P., Middlemiss, L. \& Ricci, M. (2010). Bottom-up, social innovation for addressing climate change. In: Energy Transitions in an Interdependent World: What and Where Are the Future Social Science Research Agendas, Sussex, 25-26 February.

Bergvall-Kåreborn, B., Ihlström Eriksson, C., Ståhlbröst, A. \& Svensson, J. (2009). A Milieu for innovation: Defining living labs. In: $2^{\text {nd }}$ ISPIM Innovation Symposium, New York City, USA, 6-9 December 2009 (p. 12). ISPIM.

Bijl-Brouwer, M. van der, Kaldor, L., Watson, R. \& Hillen, V. (2015). Supporting the Emerging Practice of Public Sector Design Innovation. IASDR 2015 Interplay, Brisbane, Australia.

Borzaga, C. \& Bodini, R. (2014). What to make of social innovation? Towards a framework for policy development. Social Policy and Society, 13(3), 411-421.

Brown, T. (2016). Zmiana przez design: Jak Design Thinking zmienia organizacje i pobudza innowacyjność. Wrocław: Instytut Dziennikarstwa i Komunikacji Społecznej Uniwersytetu Wrocławskiego.

Cajaiba-Santana, G. (2014). Social innovation: Moving the field forward. A conceptual framework. Technological Forecasting and Social Change, 82, 42-51.

Caulier-Grice, J., Davies, A., Patrick, R. \& Norman, W. (2012). Defining social innovation. A deliverable of the project: "The theoretical, empirical and policy foundations for building social innovation in Europe" (TEPSIE), European Commission $-7^{\text {th }}$ Framework Programme. Brussels: European Commission, DG Research.

Coorevits, L., Georges, A. \& Schuurman, D. (2018). A framework for field testing in living lab innovation projects. Technology Innovation Management Review, 8(12).

Cross, N. (2011). Design Thinking: Understanding how Designers Think and Work. Oxford: Berg.

Dekker, R., Franco Contreras, J. \& Meijer, A. (2019). The living lab as a methodology for public administration research: A systematic literature review of its applications in the social sciences. International Journal of Public Administration, 1-11.

Dorst, K. (2010). The nature of design thinking. In: Design Thinking Research Symposium. Sydney: DAB Documents, University of Technology.

Dorst, K. (2011). The core of "design thinking" and its application. Design Studies, 32(6), 521-532.

Dorst, K. \& Cross, N. (2001). Creativity in the design process: Co-evolution of problem-solution. Design Studies, 22(5), 425-437.

Dzbor, M. \& Zdrahal, Z. (2002). Design as interactions of problem framing and problem solving. In: Proceedings $15^{\text {th }}$ European Conference on Artificial Intelligence (ECAI), 21-26 Jul. 2002, Lyon, France. 
Ehn, P. (2008). Participation in design things. In: Proceedings of the Tenth Anniversary Conference on Participatory Design 2008 (pp. 92-101). Indiana University. Eriksson, M., Niitamo, V. P., \& Kulkki, S. (2005). State-of-the-art in Utilizing Living Labs Approach to User-centric Act Innovation: A European Approach. Lulea: Center for Distance-spanning Technology. Lulea University of Technology. European Commission (2019). Social Innovation. https://ec.europa.eu/growth/industry/ innovation/policy/social_en (accessed: $20^{\text {th }}$ November 2019).

Følstad, A. (2008). Living labs for innovation and development of information and communication technology: A literature review. The Electronic Journal for Virtual Organizations and Networks, 10 (Special on Living Labs), 100-131.

Gawer, A. \& Cusumano, M. A. (2014). Industry platforms and ecosystem innovation. Journal of Product Innovation Management, 31(3), 417-433.

Hillgren, P. A. (2013). Participatory design for social and public innovation: Living labs as spaces for agonistic experiments and friendly hacking. Public and Collaborative: Exploring the Intersection of Design, Social Innovation and Public Policy, 75-88.

Howaldt, J. \& Schwarz, M. (2010). Social Innovation: Concepts, Research Fields and International Trends. Aachen: Aachen University.

Ionescu, C. (2015). About the conceptualization of social innovation. Theoretical and Applied Economics, 22(3), 53-62.

Jackson, D.J. (2011). What is an Innovation Ecosystem? Arlington, VA: National Science Foundation.

Kelley, T. \& Littmann, J. (2001). The Art of Innovation. Currency and Doubleday. New York: Random House.

Kelley, D. \& Kelley, T. (2015). Twórcza odwaga. Warszawa: Wydawnictwo MT Biznes. Keyson, D., Guerra-Santin, O. \& Lockton, D. (2017). Living Labs. Cham: Springer.

Klimowicz, M. (2015). Żywe Laboratoria jako innowacyjne narzędzie zarządzania miastami. In: A. Wiktorska-Święcka (ed.), (Re)organizacja w zarzązaniu miastami w Polsce w kontekście wyzwań rozwojowych (pp. 186-197). Wrocław: Oficyna Wydawnicza ATUT.

Kwaśnicki, W. (2015). Innowacje społeczne - nowy paradygmat czy kolejny etap w rozwoju kreatywności człowieka? In: W. Misztal, G. Chimiak \& A. Kościański (eds.), Obywatelskość wobec kryzysu: uśpieni czy innowatorzy? (pp. 1-23). Warszawa: Instytut Filozofii i Socjologii PAN, http://kwasnicki. prawo.uni.wroc.pl/todownload/Innowacje SpoleczneWK.pdf (accessed: $6^{\text {th }}$ October 2018).

Leminen, S., Westerlund, M. \& Nyström, A. G. (2012). Living labs as open-innovation networks. Technology Innovation Management Review, 2(9). 
Manzini, E. (2014). Making things happen: Social innovation and design. Design Issues, 30(1), 57-66.

Mulgan, G. (2006). The process of social innovation. Innovations: Technology, Governance, Globalization, 1(2), 145-162.

Mumford, M. D. (2002). Social innovation: Ten cases from Benjamin Franklin. Creativity Research Journal, 14(2), 253-266.

Murray, R., Caulier-Grice, J. \& Mulgan, G. (2010). The Open Book of Social Innovation. London: National Endowment for Science, Technology and the Arts.

Neumeier, S. (2012). Why do social innovations in rural development matter and should they be considered more seriously in rural development research? Proposal for a stronger focus on social innovations in rural development research. Sociologia Ruralis, 52(1), 48-69.

OECD (2011). Fostering Innovation to Address Social Challenges. Workshop proceedings. Paris.

Olejniczuk-Merta, A. (2013). Innowacje społeczne. Konsumpcja i Rozwój, 1(4), 21-34.

Pol, E. \& Ville, S. (2009). Social innovation: Buzz word or enduring term? The Journal of Socio-economics, 38(6), 878-885.

Rohrbeck, R., Hölzle, K. \& Gemünden, H. G. (2009). Opening up for competitive advantage - How Deutsche Telekom creates an open innovation ecosystem. R\&D Management, 39(4), 420-430.

Romero Herrera, N. (2017). The emergence of living lab methods. In: D. Keyson, O. Guerra-Santin \& D. Lockton (eds.), Living Labs. Cham: Springer.

Schuurman, D., De Marez, L. \& Ballon, P. (2016). The impact of living lab methodology on open innovation contributions and outcomes. Technology Innovation Management Review, 6(1).

Steward, F., Liff, S., Dunkelman, M. (2009), Mapping the Big Green Challenge. NESTA Research Report, London.

Veeckman, C., Schuurman, D., Leminen, S. \& Westerlund, M. (2013). Linking living lab characteristics and their outcomes: Towards a conceptual framework. Technology Innovation Management Review, 3(12), 6-15.

Von Hippel, E. \& Von Krogh, G. (2016). Crossroads - Identifying viable "need-solution pairs": Problem solving without problem formulation. Organization Science, 27(1), 207-221.

Voorberg, W. H., Bekkers, V. J. \& Tummers, L. G. (2015). A systematic review of co-creation and co-production: Embarking on the social innovation journey. Public Management Review, 17(9), 1333-1357.

Zurbriggen, C. \& Lago, M. G. (2019). An experimental evaluation tool for the Public Innovation Lab of the Uruguayan government. Evidence \& Policy: A Journal of Research, Debate and Practice, 15(3), 437-451. 


\title{
ŻYWE LABORATORIUM INNOWACJI SPOKECZNYCH JAKO METODOLOGIA BADAŃ OPARTYCH NA DESIGNIE
}

\begin{abstract}
Abstrakt
Tło badań. Biorąc pod uwagę specyfikę i znaczenie innowacji społecznych jako procesów przekształcania nowatorskich pomysłów i rozwiąań kluczowych problemów społecznych w wartość dla społeczeństwa, nie można ich badać ani projektować, jeśli zostana oderwane od swojego naturalnego środowiska. Podejście oparte na żywych laboratoriach stało się obiecujacca metodologia badania innowacji społecznych, która oferuje możliwości tworzenia i testowania innowacji w procesach współtworzenia z użytkownikami i innymi interesariuszami w rzeczywistych warunkach.
\end{abstract}

Cel badań. Biorac pod uwagę, że koncepcja żywych laboratoriów jest przede wszystkim metodologia badawcza, niniejsze badanie ma na celu zidentyfikowanie procesów, na których opiera się funkcjonowanie żywego laboratorium innowacji społecznych jako ramy teoretycznego badań koncepcyjnych opartych na designie.

Metodologia. Badanie zostało zrealizowane za pomoca badań koncepcyjnych, w których wykorzystano istniejąca wiedzę jako źródło rozumowania prowadzącego do rozwiązania problemu naukowego. Obserwacja i analiza istniejaccych informacji o procesach poznawczych zachodzacych w żywych laboratoriach oraz ich interpretacja w świetle wiedzy o procesach tworzenia innowacji społecznych doprowadziły do rozwiąania postawionego problemu naukowego.

Kluczowe wnioski. Oryginalne ramy koncepcyjne dla badania żywych laboratoriów innowacji społecznych rozumianych jako metodologia badań i projektowania. Proponowane ramy badań umożliwiają połączenie istniejącej wiedzy z doświadczeniami $\mathrm{z}$ jej praktycznego zastosowania w celu testowania i dalszego rozwoju teorii.

Słowa kluczowe: żywe laboratoria, innowacje społeczne, design, podejście oparte na designie, badania koncepcyjne 